\title{
Biological treatment of industrial and domestic wastewater of a brewery in Uzbekistan
}

\author{
N.B. Egamberdiev, Zilola Sharipjonova, Bobur Nasibov ${ }^{*}$, A.O. Khomidov M.I. Alimova \\ A.A. Abdumalikov \\ Tashkent Institute of Irrigation and Agricultural Mechanization Engineers, Tashkent, Uzbekistan
}

\begin{abstract}
During the period of water shortage in the Republic, modern resource-saving irrigation methods and the use of purified and industrial waters and their reuse in irrigation is an urgent problem in ecology. Among the methods for treating industrial wastewater in a cheaper, cost effective way is the biological treatment method. It is the study of the effectiveness of biological treatment of industrial wastewater from primary winemaking using selected strains of aquatic plants (pistia).

The object of wastewater research is selecting a Pistia algae strain, carrying out biochemical, hydrochemical analyses of wastewater before and after treatment, and the chemical composition of the Pistia algae biomass. All studies were carried out according to the standard studies of UzGOST for waste and drinking water and algological methods used by the Institute of Botany of ANRUz, State Enterprise "Institute GIDROINGEO", etc.

The efficiency of biological purification of wastewaters of primary winemaking by higher aquatic plants of the pistia was established. With the help of the research carried out, the wastewater treatment of the food plant, in particular, the Kibray wine station with the Pistia algae, was established: - the optimal parameters of growth, development and purification capacity of pistia algae were established for various variants of experiments and wastewater samples;

- designed and assembled a semi-industrial plant for biological wastewater treatment of the Kibray wine station and carried out work on industrial wastewater treatment.

Wastewater from the Kibray wine station contains organic compounds, namely yeast sediments, proteins, fats, carbohydrates, fiber, which are food for Pistia algae. Pistia biomass obtained after cultivation in wastewater after sterilization can be used as feed in livestock and poultry farming, as it contains a large number of proteins, fats and carbohydrates.
\end{abstract}

\section{Introduction}

Today, the world's population is growing at a rapid pace, and the need for fresh drinking water is only growing. As of April 25, 2015, the population of the Earth reached

* Corresponding author: bobnasibov@gmail.com 
approximately 7 billion 289 million people, and the annual increase is approximately 83 million people. The data indicate an annual increase in fresh water demand in the amount of 64 million cubic meters. It should be noted that during the period when the world's population tripled, the use of fresh water increased 17 times [1-12].

\section{Materials and methods}

Wastewaters of the Kibray wine station and higher aquatic vegetation of the pistia (Pistia stratiotes L., family Araceae).

The Kibray wine station was founded in 1867 on the territory of the Kibray district of the Tashkent region plant area 14.5 hectares. The enterprise is adapted to the production of wine. The products are manufactured according to the old classical technology. In 2003, a loan in the amount of $\$ 5.0$ million was received from the National Bank of the Republic of Uzbekistan and equipped with the new necessary equipment. A laboratory has been established to control the quality of the products, and 12 employees are employed. Here, product acceptance and product quality are strictly controlled [13-18]. The laboratory consists of 3 parts: microbiological control, product control and chemical control. The continuous technological process of the enterprise consists of the following 3 stages:

- Reception and storage of products;

- Product processing;

- Extraction of products;

- Defending;

- Moving and storage;

The enterprise has 2 workshops:

The first of them is adapted for the production of 6.0 million liters of wine. Here, two of their 4-section units take 5.5 tons of grapes.

In the autumn period, this shop processes 50 tons of products. Here, in 1 hour, 12 thousand bottles are bottled with a volume of 0.75 liters. The second workshop is adapted for the production of 5.0 million liters of wine and built in 2004. German technology is capable of receiving 6.5 tons of grapes. For an hour, wine is bottled for 24 thousand bottles of 0.75 liters [19-26].

The composition of Kibray wine contains $4.5 \%$ alcohol, $0.2-12 \%$ must, and $46 \mathrm{kcal}$ per $100 \mathrm{~g}$ of wine energy. The water supply and sewerage workshop are used for the main and auxiliary production. Mechanical, repair, utility, control and measurement, electrical workshop, central laboratory and warehouse - all of them serve for the continuous production of wine products. The Kibray wine station uses fresh, underground waters for production purposes. There are 10 wells on the balance of enterprises, of which 7 are for household drinking purposes, 2 are reserve, 1 is used for observation. Wells used for production purposes are located (there are 7 of them) at 200m from each other: 4 of them are workers, 3 are reserve. The water extracted by the wells is distributed throughout the workshop through pipelines. Groundwater level and qualitative composition are constantly studied and monitored by observation wells. Kibray wine station discharges its household waste directly into the sewer. The results of the laboratory data of wastewater show that for the dry residue, sulfates remain vital. Wastewater treatment is carried out in two stages:

- at the cleaning station;

- in natural conditions in bio-basins.

The main part of treatment facilities, according to regulatory documents, consists of:

- sewage pumping station - KNS;

- water measuring chute - Venturi;

- distribution chamber;

-sand catchers; 
- technical blocks (primary sedimentation tanks, aerotanks, secondary sedimentation tanks, aerobic tanks, clean water);

- chlorosporus;

- sandy areas;

-bio-basins;

- emergency basins $\left(2850 \mathrm{~m}^{3}\right)$.

The sewage pumping station cleans wastewater from large mixtures and delivers them to the treatment plant. Before entering the sewage pumping station, wastewater passes through the grates (one-working). The second backup grates purify wastewater from coarse mixtures. These mixtures are decomposed into a common drain, then through a Venturi meter into a sand catcher. The Venturi meter is used to measure the flow of wastewater.

The maximum wastewater flow rate reaches $1 \mathrm{~m} 3 / \mathrm{sec}$. Sand catchers are used to purifying wastewater from large impurities; otherwise, the pipes wear out due to mechanical tendency. Waste water after the grit catchers goes into the distribution chamber, then the technological block. All technological blocks are connected into two sections, the width of which is $15 \mathrm{~m}$ each. Wastewater is purified from impurity molecules within 2 hours. Primary sedimentation tanks are the last stage of mechanical wastewater treatment. Aeration tanks are used for biological wastewater treatment. In them, organic matter of wastewater is oxidized and biologically treated. After the aeration tank, the wastewater passes through the secondary sedimentation tanks, then, after purification, into the biopools with an area of $1120 \mathrm{~m} 2$.

Organic and mineral substances decompose with the help of microorganisms, and wastewater is purified under the influence of hydrobiotics. Algae enrich them with oxygen, accelerating the action of microorganisms. In bio-basins, tall aquatic plants are used to absorb bioelements from wastewater. In bio-basins, wastewater is stored for 6-7 days.

Emergency reservoirs are designed to receive wastewater in emergency situations. The reservoirs are located before the KIS, and they are capable of receiving wastewater equal to half the volume of daily wastewater. There are 100 kinds of them on the water basins of our Republic [27-29].

Tall aquatic wetland plants differ from other straws in yield. Tall aquatic plants act as a filter and enrich the water with dissolved oxygen. The amount of organic matter and BOD decreases. In addition, there are certain types of aquatic plants, enriched with glycoside, essential oils, and it is used as a raw material in the production of medicines. Currently, the role, flora, modern system, and tall water-boggy plants of Uzbekistan are studied insufficiently.

Pistia (Pistia stratiotes), or, as it is also called, water salad, is an aquarium plant of the Aroid family (Araceae). In nature, Pistia lives in the waters of the tropics and subtropics of Africa. Water salad is a rosette of greenish-bluish large leaves floating on the water, velvety to the touch. The diameter of one such outlet is about $25 \mathrm{~cm}$. Pistia is a floating plant and forms a blue-green rosette. The growth of the pistia in the conditions of Uzbekistan reaches $20-40 \mathrm{~cm}$; the trunk is $5-8 \mathrm{~cm}$, the length of the leaves is $15-22 \mathrm{~cm}$. Pistia is placed vegetatively. Pistia grown on wastewater from livestock complexes and industrial enterprises produces up to $1 \mathrm{~kg} / \mathrm{m}^{2}$ of biomass. Mass flowering of the Pistia and harvesting occurs during the hot months. (June-August) of the year. Autogamy of the pistia occurs by the method. The root feeding system mainly consists of young roots $50-60 \mathrm{~cm}$ long. In open places, plants are pissed until November, in warm ones all year round. Pistia - placed with stolon. A young plant usually produces 4 leaves. Fruit leaves are dry, closed, contains many cylindrical lice $(1.5-3 \mathrm{~cm})$. The weight of 1000 seeds is 2.1-2.2 g. Growing tall aquatic plants is carried out in laboratory conditions. Also used watercolours, crystallizers, duralumin dishes, concreted pools. These aquatic plants are intended for wastewater treatment of the Kibray wine station [12]. The height of large specimens can reach $15 \mathrm{~cm}$. 
Pistia deserves the title of one of the most beautiful plants that float on the surface of the water. The root system of the water lettuce is well developed and consists of deeply dropping roots (up to $30 \mathrm{~cm}$ ). This plant is widespread among aquarists. Both open reservoirs and aquariums are suitable for its maintenance. The long roots of the pistia cleanse the water well from mud. In addition, the interlacing of the roots is a good refuge for fry and a spawning ground for aquarium fish. Under comfortable conditions, water lettuce grows evenly throughout the year, forming thickets that practically do not transmit light and thereby shade benthic plants. To avoid a strong blackout, it is necessary to thin out these thickets periodically. The content of the pistia is not capricious. The optimum water temperature for plant growth and development is within $24-30^{\circ} \mathrm{C}$ in summer and $18-20^{\circ} \mathrm{C}$ in winter. In colder water, growth slows down. The plant is indifferent to other quality indicators of water, namely hardness and reaction. But, nevertheless, with higher water hardness, the pistia grows worse. The main thing that is important for a water salad is aquarium lighting, which should be bright, at least 12 hours a day. The plant reaches its maximum size in natural sunlight. When using an artificial one, fluorescent lamps with a power of $3 \mathrm{~W} /$ liter or more are used. Incandescent lamps are not recommended for use as a means of artificial lighting because the heat emanating from these lamps causes leaf burns. It is recommended to cover the aquarium with glass to create a humid atmosphere saturated with water vapor. Under conditions of such an atmosphere, sufficient temperature and lighting, the pistia produces a small peduncle. For the content of water lettuce, the nature of the soil does not matter at all since often the roots of this plant do not reach the bottom, and it floats freely on the surface of the water. Complex mineral dressing must be done during the period of rapid growth, spring and summer. Trace elements are included in the feed. Feeding is carried out weekly with the expectation that 1.5-2 grams of fertilizers are applied to 100 liters of water. It is also recommended to make a weekly water change [7].

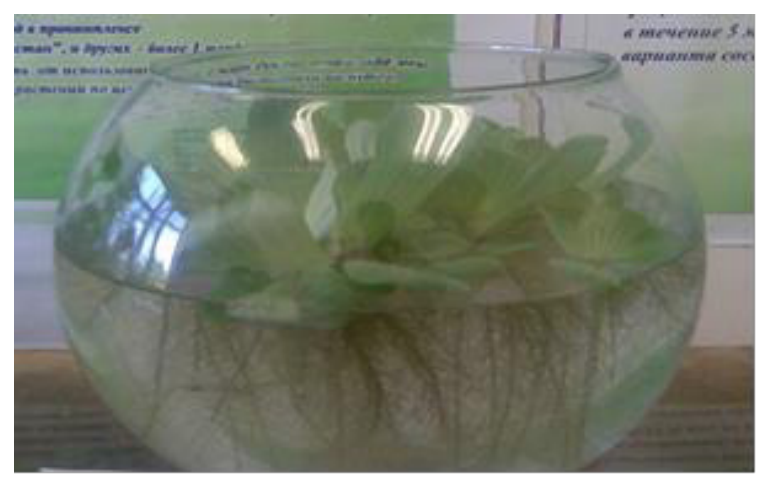

Fig. 1. General view of pistia when grown in a laboratory 


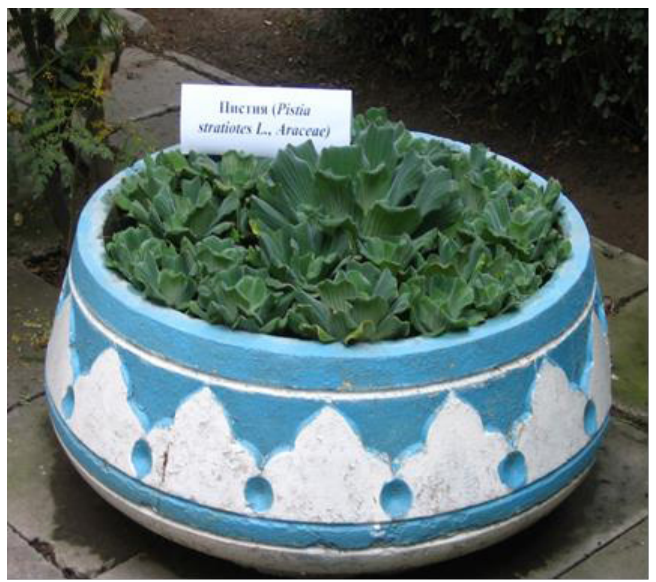

Fig. 2. Pistia seedlings grown in special concrete ponds in the open air

Description of the methodology used in the study: laboratory, chemical and statistical methods.

\section{Results and Discussion}

Study of the physical and chemical parameters of industrial wastewater from the Kibray winery. Kibray wine station (the results of the analysis of laboratory work of the wine point were carried out in the laboratory of GIDROINGEO)

Table 1

\begin{tabular}{|c|c|c|}
\hline Indicators & July 2018 & March 2019 \\
\hline Smell & Specific smell & Specific smell \\
\hline Colour & Colorless, cloudy & Colorless, cloudy \\
\hline $\mathrm{pH}$ & 6.70 & 6.95 \\
\hline Dissolved oxygen $\mathrm{mg} / \mathrm{O}_{2} / 1$ & 5.92 & 4.92 \\
\hline $\mathrm{BOD} 5 \mathrm{mg} / \mathrm{O}_{2} / 1$ & 6.15 & 8.30 \\
\hline $\mathrm{COD} \mathrm{mg} \mathrm{/} \mathrm{O}_{2} / 1$ & 10.42 & 15.21 \\
\hline Oxidizability mg / $\mathrm{O}_{2} / 1$ & 4.70 & 5.50 \\
\hline Sodium mg / & 19.0 & 7.0 \\
\hline Potassium mg / 1 & 6.10 & 6.0 \\
\hline Ammonium mg / & 6.0 & 3.9 \\
\hline Calcium mg / 1 & 6.0 & 5.4 \\
\hline Chloride $\mathrm{mg} / 1$ & 16 & - \\
\hline Magnesium mg / 1 & 18 & 27 \\
\hline Sulphates mg / & 81 & 60 \\
\hline Nitrates mg / & 11 & 3 \\
\hline Chlorides & 16 & 6.94 \\
\hline Phosphates & 0.71 & \\
\hline
\end{tabular}

As follows from table 1 performed in the laboratory of water problems of the State Enterprise "Institute GIDROINGEO" in wastewater samples taken in July 2018 and in March 2019, BOD, COD, potassium, sulfates, etc. do not meet the requirements of GOST, so they had to be purified.

Chemical indicators before and during the cultivation of higher aquatic vegetation in Kibray wine station (laboratory experiments, July 2018) 
Table 2

\begin{tabular}{|c|c|c|c|c|c|c|}
\hline $\begin{array}{c}\text { Sampling } \\
\text { date }\end{array}$ & $\mathrm{pH}$ & Colour & Smell & $\begin{array}{c}\mathrm{COD} \\
\mathrm{mg} / \mathrm{O}_{2} \\
/ 1\end{array}$ & $\begin{array}{c}\mathrm{BOD} 5 \\
\mathrm{mg} / \mathrm{O}_{2} / 1\end{array}$ & $\begin{array}{c}\text { Oxidizability } \\
\mathrm{mg} / \mathrm{O}_{2} / 1\end{array}$ \\
\hline \multicolumn{7}{|c|}{ Wastewater before treatment (control) } \\
\hline $\begin{array}{c}1 \text { july } \\
2018\end{array}$ & 6.70 & $\begin{array}{c}\text { No } \\
\text { color }\end{array}$ & $\begin{array}{c}\text { Not a } \\
\text { pleasant } \\
\text { smell }\end{array}$ & 6.15 & 10.42 & 4.70 \\
\hline \multicolumn{7}{|c|}{ Wastewater after planting a pistia (experiment) } \\
\hline $\begin{array}{c}20 \text { july } \\
2018\end{array}$ & 7.2 & $\begin{array}{c}\text { No } \\
\text { color }\end{array}$ & $\begin{array}{c}\text { without } \\
\text { smell }\end{array}$ & 1.95 & 2.52 & 1.23 \\
\hline $\begin{array}{c}10 \text { August } \\
2018\end{array}$ & 7.4 & $\begin{array}{c}\text { No } \\
\text { color }\end{array}$ & $\begin{array}{c}\text { without } \\
\text { smell }\end{array}$ & 1.89 & 3.71 & 1.35 \\
\hline
\end{tabular}

Chemical indicators before and during the cultivation of higher aquatic vegetation in Kibray wine station (laboratory experiments, March 2019).

Table 3

\begin{tabular}{|c|c|c|c|c|c|c|}
\hline $\begin{array}{c}\text { Sampling } \\
\text { date }\end{array}$ & $\mathrm{pH}$ & Colour & Smell & $\begin{array}{c}\mathrm{COD} \mathrm{mg} / \\
\mathrm{O}_{2} / \mathrm{l}\end{array}$ & $\begin{array}{c}\mathrm{BOD} 5 \\
\mathrm{mg} / \mathrm{O}_{2} / 1\end{array}$ & $\begin{array}{c}\text { Oxidizability } \\
\mathrm{mg} / \mathrm{O}_{2} / 1\end{array}$ \\
\hline \multicolumn{7}{|c|}{ Wastewater before treatment (control) } \\
\hline $\begin{array}{c}10 \text { March } \\
2019\end{array}$ & 6.9 & No color & $\begin{array}{c}\text { Not a } \\
\text { pleasant } \\
\text { smell }\end{array}$ & 8.30 & 15.21 & 5.50 \\
\hline \multicolumn{7}{|c|}{ Wastewater after planting a pistia (experiment) } \\
\hline $\begin{array}{c}20 \text { April } \\
2019\end{array}$ & 7.65 & No color & $\begin{array}{c}\text { without } \\
\text { smell }\end{array}$ & 1.97 & 2.64 & 1.33 \\
\hline $\begin{array}{c}10 \text { April } \\
2019\end{array}$ & 7.60 & No color & $\begin{array}{c}\text { without } \\
\text { smell }\end{array}$ & 1.90 & 3.83 & 1.48 \\
\hline
\end{tabular}

$10 \mathrm{~m}$

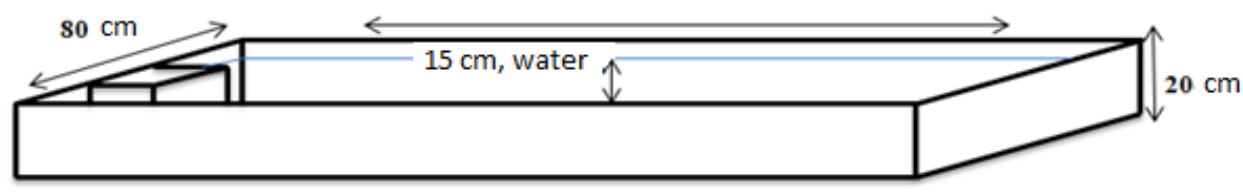

$10 \mathrm{~m}$

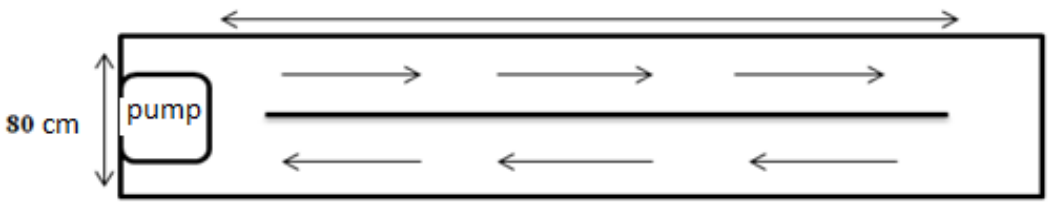

Fig. 3. Semi-industrial plant diagram 
Physicochemical parameters before and during the cultivation of higher aquatic plants in Kibray wine station after a month of the experiment (laboratory research, April 2019)

Table 4

\begin{tabular}{|c|c|c|c|c|c|c|c|c|c|c|c|}
\hline \multirow[b]{2}{*}{ № } & \multirow[b]{2}{*}{ Experiences } & \multicolumn{10}{|c|}{ Indicators } \\
\hline & & 茎 & $\frac{\overline{0}}{0}$ & 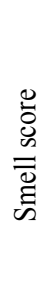 & 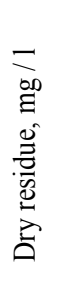 & 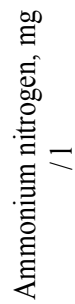 & 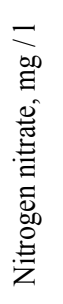 & 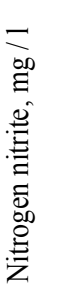 & $\begin{array}{l}\underset{0}{\sigma} \\
\underset{\Xi}{0} \\
\hat{0}\end{array}$ & 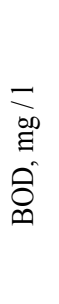 & 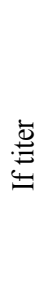 \\
\hline 1 & $\begin{array}{c}\text { Wastewater } \\
75 \% \text { drinking } \\
\text { water } 25 \%\end{array}$ & 7.2 & cloudy & no & 680 & 2 & - & - & 13.8 & 6 & 3 \\
\hline 2 & $\begin{array}{c}\text { Waste water } \\
50 \% \text { drinking } \\
\text { water } 50 \%\end{array}$ & 7.2 & $\begin{array}{l}\text { light } \\
\text { coloure } \\
\text { d }\end{array}$ & no & 570 & 1 & - & - & 11.5 & 4 & 3 \\
\hline 3 & Control knop & 7.2 & $\begin{array}{l}\text { very } \\
\text { cloudy }\end{array}$ & 4 & 1200 & 10.3 & 0.08 & 0.07 & 24.1 & 61 & 4 \\
\hline
\end{tabular}

Table 3, 4 presents the results of semi-industrial experiments for March, April 2019. As follows from the tables, the winery's wastewater has improved both in chemical and biological indicators; it can be used as irrigation water for agricultural crops and the technical needs of the enterprise.

According to the given data, the composition of the Pistia biomass expressed in the wastewater of the Kibray wine station contains $22.1 \%$ protein, $2.67 \%$ fat, $28.5 \%$ fiber, $9.0 \%$ moisture, $5.43 \%$ ash, $23.77 \%$ carotene.

This part contains the data of chemical analyzes. In laboratory conditions, higher aquatic plants of the pistia were grown on wastewater. The daily yield was 31.6 grams, for 15 days, 315.02 grams.

\section{Conclusions}

1. Wastewater of the Kibray wine station contains organic compounds, namely yeast sediments, proteins, fats, carbohydrates, fibers, which are food products for pistia algae.

2. As a result of the cultivation of Pistia algae in this wastewater, the water is purified from organic compounds.

3. The biological method of wastewater treatment is economically profitable since it does not require large expenditures to purchase special structures and reagents for physicochemical, mechanical treatment methods.

4. Biologically purified wastewater of the Kibray wine station with algae pistia can be used again for the technical needs of the plant, that is, for washing tanks, equipment and can be used for irrigation of agricultural crops. 
5. The biomass of the pistia obtained after growing in wastewater after sterilization can be used as feed in livestock and poultry farming since it contains many proteins, fats and carbohydrates.

\section{References}

1. Abdurakhimov Kh., Ismailkhadzhaev B. Development of an integrated technology for purification of wastewater from cellulose production, p. 327, Tashkent, (2019)

2. Aitmetova K.I. The role of corpus luteum and eichornia excellent in wastewater treatment of the Chirchik production association, Tashkent, Botanical Institute and Botanical Garden, p. 144, (2016)

3. Beideman I.N. Methods for studying the phenology of plants and plant communities. p. 153, Novosibirsk, (2014)

4. Galkina N.B. Aquatic plants as industrial wastewater purifiers copper, zinc, lead Abstracts of reports of scientific and technical conference, On the use of wastewater in agriculture, p. 312, Tashkent, (2012)

5. Golubovskaya E.K. Biological bases of water purification, p. 267, Moscow, High school, (2018)

6. Grushko Y.M. Harmful organic compounds in industrial wastewater, A Handbook., p. 214, Chemistry, (2013)

7. Gudkov A.G. Biological treatment of municipal wastewater, p. 127, Vologda, VOTSU, (2012)

8. Dai Kuan-yu, Yang-dzhao, Chang Hen. Investigation of wastewater treatment from silver water hyacinth, Phytoecol Acts. et Geobot. Sci., 16(1), pp.11-16.

9. Dai Qianyu, Chen Yuangao, Kyo Yu, Zhang Han. Purification by water hyacinths silver of wastewater from the plant for the production of film, Acta. Sci Circumstantiae, № 3, pp.362-370, (2015)

10. Dikieva D.M., Petrova I.A. The chemical composition of macrophytes and factors determining the concentration of mineral substances in higher aquatic plants, Hydrobiological processes in voemakh, p. 213, Leningrad, Nauka, (2018)

11. Ding Yanhua. Investigation of an exemplary project of a wastewater treatment system on humid lands with reed thickets, Khim. J. Environ Sci. № 2, pp. 8-13, (2018)

12. Direnko A.A., Knus A., Kotsar E.M. The use of higher aquatic plants in the practice of wastewater treatment and surface runoff, Sanitary engineering and water supplyб № 5, p. 186, Moscow, (2016)

13. Dmitrieva N.G., Einor L.O. The role of macrophytes in the conversion of phosphorus in water, Water. Resources, № 5, p. 341, (2015)

14. Ermakov A.I., Arasimovich V.V., Smirnova-Ikonnikova M.I., Yarosh N.P., Lukovnikova G.A. Biochemical research methods of plants, p. 456, (2012)

15. Zhumaniyazova G.I. Microorganisms of the breeze plant wastewater and their participation in biological treatment with the help of teloresis, p. 20, Tashkent, (2015)

16. Zaitsev G.N. Mathematical statistics in experimental botany, p. 424, Moscow, (2011)

17. Ilyaletdinov A.N., Alieva R.M. Microbiology and biotechnology of industrial water purification, Alma-Ata: Nauka, p. 224, (2014)

18. Katanskaya V.M. Materials for studying the productivity of thickets of aquatic plants in the delta of the Amu Darya, Proceedings of the lab., Lake Scientist, Academy of Sciences, 10, p. 249, (2017)

19. Katanskaya V.M. Higher aquatic vegetation of the continental reservoirs of the USSR, p. 187, (2018)

20. Kalinina E.V. Decrease in the content of biogenic elements in the process of biological treatment of urban wastewater by higher aquatic plants, p. 26, Perm, (2017) 
21. Karimov Kh.K. Waste waters of primary treatment plants of kenaf, On the production culture of unicellular algae, p. 122, Tashkent, (2006)

22. Keldibekov. C. Flora and vegetation of fishponds in the Chirchik-Angren basin, p. 116, Tashkent, (2016)

23. Kokin K.A. Ecology of higher aquatic plants, p. 160, Moscow, (2014)

24. Mole Yu.G. The use of higher aquatic plants in biotechnologies for the purification of surface and wastewaters, Hydrobiological journal, 42(1), p. 191, (2016)

25. Kuznetsov S.I., Kazarovets N.M., Margolina G.L. Determination of the intensity of the process of self-purification of water in reservoirs, Materials on biology and hydrobiology of the Volga reservoirs, Academy of Sciences of the USSR, p. 96, (2013)

26. Kutliev J., Tashpulatov Zh.Zh., Shoyakubov U.R., Urinova A.A., Khushmuradova G.K. The use of microorganisms and macrophytes for wastewater treatment of JSC "Navoiazot" and biofuel production, Actual problems of algology, mycology and hydrobotany: Materials of the international scientific conference, p. 254, Tashkent, (2019)

27. Lurie Y.Y. Unified methods for water analysis, p.376, Moscow, (2013)

28. Lurie Y.Y. Analytical chemistry of industrial wastewater, Industrial wastewater, p.447 Moscow, (2012)

29. Madalieva G.K. Flora and vegetation of wastewater bodies of the Tashkent oasis and their role in self-purification of waters, p. 31, Tashkent, (2017) 